\title{
Natural Killer Cell Activity Measurement
}

National Cancer Institute

\section{Source}

National Cancer Institute. Natural Killer Cell Activity Measurement. NCI Thesaurus. Code C116203.

The determination of the amount of natural killer cell activity in a sample. 